\title{
ANALISIS PREFERENSI PETANI TERHADAP MODEL KEMITRAAN KELAPA SAWIT DENGAN METODE ANP (ANALYTIC NETWORK PROCESS)
}

\section{PALM OIL' PARTNERSHIP MODEL-BASED ON FARMER PREFERENCES USING ANP METHOD (ANALYTIC NETWORK PROCESS)}

\author{
Suparjan $^{1 *}$ dan An Naafi Yuliati Lathifah ${ }^{1)}$ \\ Forbil Institute, Jalan Sunan Giri, RT 01/RW 25, Kec. Ngaglik, Sleman 55581, DIY, Indonesia \\ *E-mail: suparjan.ugm@gmail.com \\ Makalah: Diterima 17 Juli 2020; Diperbaiki 31 Oktober 2020; Disetujui 15 November 2020
}

\begin{abstract}
The palm oil's partnership model in Indonesia, which is dominated by smallholders in practice, still finds injustices where farmers do not have the same bargaining power as the company although their relationship is as partners. This study aimed to develop a partnership model that considers the conditions of farmers as part of a valuable partner to carry out equality in the partnership itself using indicator profitability, social welfare, and replanting. The Analytic Network Process (ANP) was used to determine the priority of indicator in partnership model considered as the most important for oil palm farmers by comparing the available criteria and alternative factors. It is known fro this study that the oil palm farmer chooses the priority of model partnership with cooperation model and the criteria for agreement, transparency, and saving mechanism for replanting farmers in developing a model of the partnership of oil palm farmers in Indonesia.
\end{abstract}

Keywords: analytic network process, partnership model, oil palm farmers

\section{ABSTRAK}

Model kemitraan petani sawit di Indonesia yang didominasi oleh petani kecil pada praktiknya masih ditemukan ketidakadilan seperti petani yang memiliki daya tawar lebih rendah dibandingkan perusahaan sebagai mitranya. Keberlanjutan usaha perkebunan kelapa sawit ditentukan oleh faktor profitabilitas, kesejahteraan sosial, dan jaminan peremajaan kebun yang terdapat pada jenis kemitraan individu, koperasi, maupun perusahaan. Penelitian ini bertujuan untuk mengembangkan model kemitraan berdasarkan preferensi petani, sehingga diharapkan dapat menciptakan kesetaraan. Metode ANP (Analytic Network Process) digunakan untuk mengetahui prioritas petani sawit terhadap model kemitraan dengan membandingkan faktor kriteria dan alternatif yang tersedia. Diketahui dari penelitian ini bahwa kemitraan koperasi dengan kriteria penaatan perjanjian, transparansi, dan mekanisme tabungan peremajaan kebun yang jelas merupakan model yang menjadi prioritas petani dalam pengembangan model kemitraan petani sawit di Indonesia.

Kata kunci: analytic network process, model kemitraan, petani kelapa sawit

\section{PENDAHULUAN}

Kontribusi industri sawit Indonesia terhadap Produk Domestik Bruto (PDB) Indonesia sangat besar. Ditjenbun mengklaim bahwa pada 2016, sektor perkebunan sawit berkontribusi sebesar Rp 239,4 triliun terhadap PDB sektor perkebunan yang mencapai Rp 429 triliun. Hal tersebut disebabkan oleh jumlah petani sawit di Indonesia yang cukup besar. Jumlah petani sawit di seluruh Indonesia pada tahun 2017 mencapai 2.213.037 KK (Ditjenbun, 2017). Dimensi manusia dalam perkebunan sawit menarik perhatian karena penggunaan lahan sawit didominasi oleh petani kecil. Petani kecil ini mendominasi $41 \%$ dari total area kelapa sawit dan $36 \%$ dari total tandan buah segar di Indonesia (ISPOC, 2012).

Di sisi lain, sektor perkebunan kelapa sawit memerlukan integrasi dari hulu ke hilir dikarenakan komoditas kelapa sawit tidak bisa langsung dinikmati oleh konsumen akhir sehingga membutuhkan integrasi dengan industri pengolahan. Dalam rangka mengoptimalkan sektor kelapa sawit untuk meningkatkan pertumbuhan ekonomi dan kesejahteraan masyarakat sekitar, kemitraan intiplasma direkomendasikan pemerintah melalui UU No. 18 Tahun 2004 tentang Perkebunan. Salah satu poin dari aturan tersebut juga mengharuskan industri pengolahan untuk bermitra dengan petani/usaha perkebunan. Meski begitu, hingga 2017 hanya terdapat $27 \%$ dari petani yang tergabung ke dalam kemitraan, sisanya $71 \%$ petani belum tergabung ke dalam kelembagaan petani apapun. Oleh karena itu, penting untuk mengetahui bagaimana preferensi petani sawit dalam memilih model kemitraan terbaik agar mendorong terciptanya kemitraan-kemitraan baru.

Dari kemitraan yang sudah ada, secara umum terdapat tiga jenis kemitraan sawit berdasarkan temuan riset di Kalimantan Tengah yang terdiri dari kemitraan koperasi, kemitraan plasma dikelola perusahaan, dan kemitraan individu (Suharno et al., 
2015). Penelitian sebelumnya menemukan bahwa di dalam program kemitraan, perusahaan dan petani tidak memiliki posisi tawar yang sejajar meskipun keduanya merupakan pihak yang saling bekerja sama. Hal yang sama ditemukan pada pelaksanaan pola kemitraan di Kabupaten Aceh Jaya, bahwa perusahaan dan petani mitra tidak memiliki kedudukan yang sejajar. Dari segi keadilan (fairness), perusahaan inti merupakan pihak yang mempunyai posisi yang lebih kuat dibandingkan masyarakat yang cenderung punya nilai tawar yang lebih rendah. Sebagai contoh, dalam hal penentuan isi perjanjian, perusahaan pemodal mempunyai kewenangan lebih tinggi dibandingkan petani (Milsa, 2015). Hasil penelitian di Kalimantan Barat tepatnya di Koperasi Unit Desa SP II Bhakti Jaya menemukan bahwa relasi antara petani plasma dan KUD kurang baik padahal KUD berperan sebagai mediator di dalam kemitraan. KUD kurang mendukung petani untuk melakukan advokasi dan negosiasi dengan perusahaan (Oktaby, 2014).

Suatu kemitraan juga diharapkan dapat mendorong percepatan pertumbuhan ekonomi daerah dengan meningkatkan pendapatan petani serta dapat menguntungkan kedua belah pihak, perusahaan dan masyarakat sekitar (Nurhayati et al., 2016). Hal tersebut menjustifikasi pentingnya aspek keuntungan dalam suatu kemitraan. Selain itu, strategi kemitraan bisnis yang sukses sangat ditentukan oleh kepatuhan antara mitra dalam menjalankan etika bisnisnya (Hamid et al., 2018). Oleh karena itu, penyusunan model kemitraan yang mempertimbangkan daya tawar petani sebagai mitra penting dilakukan untuk menciptakan hubungan kemitraan yang adil dan mematuhi aturan perjanjian yang ada serta mencapai keuntungan yang diharapkan bagi kedua belah pihak.

Analytic Network Process (ANP) biasa digunakan sebagai alat pengambilan keputusan, terutama dalam menentukan prioritas. Jeon et al. (2016) menggunakan ANP sebagai pendekatan dalam memilih partner terbaik dalam proses A\&D
(Acquisition and Development) dengan menggunakan 25 kriteria. Sadeghi et al. (2012) menggunakan ANP dalam pemilihan partner strategis bagi Fars Gas Company, dimana seorang manajer dihadapkan pada permasalahan multi-criteria decision-making. Ikatrinasari et al. (2011), menggunakan ANP untuk memilih model kelembagaan dalam pengembangan kawasan agropolitan di Probolinggo dengan membandingkan beberapa kriteria dan alternatif model kelembagaan yang paling diprioritaskan.

Penelitian ini menggunakan Analytic Network Process sebagai metode utama untuk mengetahui preferensi petani sawit sebagai bagian dari mitra untuk menentukan model kemitraan yang mempertimbangkan aspek profitabilitas, sosial, dan peremajaan kebun. Penelitian ini bertujuan untuk mengembangkan model kemitraan sawit berdasarkan preferensi petani sehingga diharapkan dapat mencapai keadilan bagi petani kecil yang mendominasi sektor perkebunan sawit.

\section{METODE PENELITIAN}

\section{Kerangka Pemikiran}

ANP merupakan pengembangan dari metode pengambilan keputusan yang sudah ada sebelumnya, yaitu AHP (Analytic Hierarchy Process). Pada banyak kasus pengambilan keputusan, tidak bisa hanya didasarkan pada struktur hirarki, dimana elemen yang lebih tinggi (kriteria) akan mempengaruhi elemen dibawahnya (alternatif). Kriteria dan alternatif yang saling terkait dan mempengaruhi satu sama lain dalam pengambilan keputusan tidak bisa diakomodir oleh AHP. Oleh karena itu, ANP digambarkan dengan jaringan dan bukan hirarki dimana di dalamnya terdapat hubungan timbal balik yang dapat menghasilkan keputusan yang layak dipilih di masa depan (Saaty, 2008). Kerangka pemikiran dalam penelitian ini terdiri dari empat bagian, yaitu perumusan tujuan, studi pendahuluan, analisis, dan hasil akhir (Gambar 1).

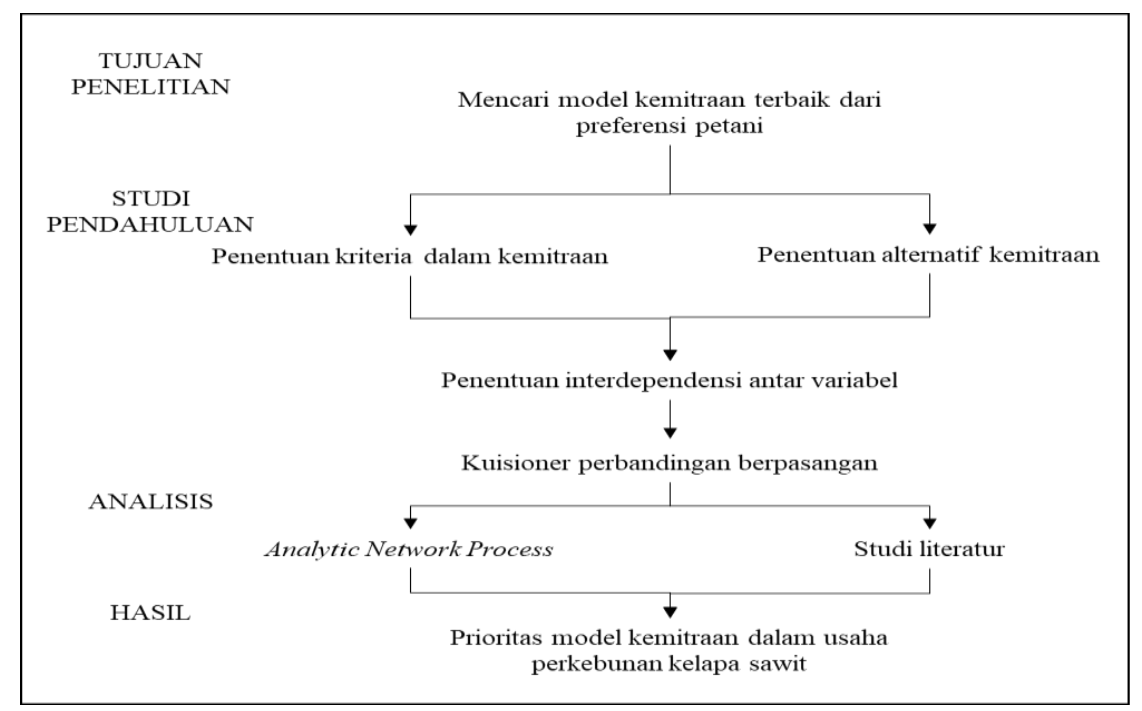

Gambar 1. Kerangka Berpikir 
Hasil penelitian dijadikan rekomendasi pengambilan keputusan dalam penentuan model kemitraan sawit berdasarkan preferensi petani sawit. Analisis preferensi petani terhadap model kemitraan sawit didasarkan pada data dari 3 wilayah sampel, yaitu Pangkalan Bun, Katingan, dan Banyuasin. Analytic Network Process (ANP) digunakan karena adanya faktor yang saling ketergantungan antara jenis kemitraan dengan kriteria dalam pemilihan kemitraan itu sendiri. Jenis kemitraan yang ada akan mempengaruhi tingkat profitabilitas, kondisi sosial petani, dan bagaimana pengelolaan tabungan peremajaan kebun dari petani. Begitu pula sebaliknya, setiap kriteria yang ada akan mempengaruhi jenis kemitraan yang akan menjadi prioritas petani.

Kemitraan individu berarti bahwa tiap individu mengelola secara mandiri kebun miliknya yang kemudian mendapat bantuan dari perusahaan mitra. Kemitraan koperasi berarti bahwa pengelolaan kebun dilakukan di bawah manajerial koperasi yang bekerjasama dengan perusahaan mitra. Terakhir, kemitraan perusahaan berarti bahwa perkebunan dikelola di bawah manajerial perusahaan, dimana pendapatan petani dikelola langsung oleh perusahaan. Tiga jenis kemitraan tersebut kemudian menjadi alternatif dalam penentuan prioritas model kemitraan.

Kriteria dalam kuesioner dipilih berdasarkan kerangka teori Triple Bottom Line. Konsep Triple Bottom Line merupakan kerangka keberlanjutan yang menganalisis dampak ekonomi, lingkungan dan sosial dari suatu usaha (HBR, 2019). John Elkington berpendapat bahwa suatu usaha harus mempersiapkan tiga kerangka dasar. Kerangka pertama adalah "profit" dari usaha, kedua adalah "people" dimana usaha memiliki tanggung jawab sosial di lingkungan sekitarnya, dan ketiga adalah "planet" yang berarti usaha tersebut juga memiliki tanggung jawab lingkungan (The Economist, 2009). Interaksi berimbang antara aspek ekonomi, sosial, dan lingkungan belum dapat dikonfirmasi, yang mana apabila usaha berfokus pada aspek sosial dan lingkungan akan sulit bagi usaha untuk mencapai aspek ekonomi, begitu pula sebaliknya (Hourneaux et $a l ., 2018)$. Oleh karena itu, dalam penelitian ini akan dilihat bagaimana preferensi petani kelapa sawit terhadap ketiga aspek tersebut, apakah menganggap pentingnya keberimbangan dari setiap aspek ataukah terdapat aspek tertentu yang lebih atau paling dominan.

Teori tersebut kemudian dielaborasikan dengan studi pendahuluan di lapangan serta dilakukan diskusi mendalam dengan seorang akademisi sebagai ahli dalam penerapan ANP untuk menghasilkan kriteria dalam kemitraan. Formulasi kriteria dalam ANP dapat dilihat pada Tabel 1

Kluster dan kriteria tersebut kemudian dituangkan ke dalam kuesioner perbandingan berpasangan yang terbagi menjadi tiga bagian, bagian pertama berisi pertanyaan perbandingan berpasangan antar kluster, bagian kedua berisi pertanyaan perbandingan berpasangan antar kriteria, dan bagian ketiga berisi pertanyaan perbandingan berpasangan antar alternatif.

Tabel 1. Kluster dan kriteria dalam penilaian preferensi kemitraan petani kelapa sawit

\begin{tabular}{|c|c|c|}
\hline Kluster & Kriteria & Keterangan \\
\hline \multirow[t]{4}{*}{ Profitabilitas } & Produksi TBS & Jumlah produksi ton tandan buah segar yang dihasilkan dalam kemitraan. \\
\hline & Harga TBS & $\begin{array}{l}\text { Rata-rata harga tandan buah segar per kg yang diterima oleh petani sawit } \\
\text { dalam kemitraan. }\end{array}$ \\
\hline & Produksi/Ha/tahun & $\begin{array}{l}\text { Biaya produksi yang dikeluarkan oleh petani dalam kemitraan yang terdiri } \\
\text { dari biaya pengolahan, pemeliharaan, pemupukan, pemanenan, dan } \\
\text { komnponen biaya produksi lainnya. }\end{array}$ \\
\hline & Pendapatan bersih & $\begin{array}{l}\text { Keuntungan bersih yang diterima oleh petani dalam kemitraan, yang } \\
\text { didapatkan dari (Produksi x Harga TBS) - Biaya Produksi. }\end{array}$ \\
\hline \multirow[t]{4}{*}{ Sosial } & Keadilan & $\begin{array}{l}\text { Risiko dan keuntungan dibagi secara adil antar berbagai pihak yang } \\
\text { terlibat dalam perjanjian serta adanya kesetaraan daya tawar. Keadilan } \\
\text { pada tingkat peraturan dan penegakan hukum. }\end{array}$ \\
\hline & Jaminan sosial & $\begin{array}{l}\text { Jaminan sosial meliputi jaminan kesehatan, jaminan kecelakaan kerja, } \\
\text { jaminan pemutihan uang, dan bahkan replanting (kelanjutan usaha } \\
\text { perkebukan sawit). }\end{array}$ \\
\hline & Penaatan perjanjian & $\begin{array}{l}\text { Penataan perjanjian kemitraan berlangsung dengan adil, tidak ada pihak } \\
\text { yang dirugikan dan melanggar perjanjian. Selain itu juga sesuai dengan } \\
\text { perundangan yang berlaku dan komitmen untuk proses implementasi } \\
\text { perjanjian. }\end{array}$ \\
\hline & Transparansi & $\begin{array}{l}\text { Keterbukaan informasi terkait perjanjian kemitraan dan dalam proses } \\
\text { pelaksanaan kerjasama, dokumen yang mudah diakses, serta keterbukaan } \\
\text { informasi terkait proses pembentukan harga TBS (acuan harga yang } \\
\text { digunakan). }\end{array}$ \\
\hline Replanting & $\begin{array}{l}\text { Tabungan peremajaan } \\
\text { kebun (replanting) }\end{array}$ & $\begin{array}{l}\text { Mekanisme sumber pendanaan peremajaan kebun, skema peremajaan } \\
\text { kebun pada kemitraan, dan skema pembagian bunga pendapatan peremajaan } \\
\text { kebun pada kemitraan }\end{array}$ \\
\hline
\end{tabular}


Tabel 2. Skala penilaian perbandingan berpasangan

\begin{tabular}{|c|c|c|}
\hline $\begin{array}{l}\text { Intensitas } \\
\text { Kepentingan }\end{array}$ & Defisini & Keterangan \\
\hline 1 & Sama penting & Dua kegiatan berkontribusi sama terhadap tujuannya. \\
\hline 3 & Sedikit lebih penting & $\begin{array}{l}\text { Pengalaman dan penilaian suatu kegiatan sedikit } \\
\text { berkontribusi atas yang lain. }\end{array}$ \\
\hline 5 & Lebih penting & $\begin{array}{l}\text { Pengalaman dan penilaian suatu kegiatan berkontribusi } \\
\text { sangat kuat atas yang lain, menunjukkan dominasi. }\end{array}$ \\
\hline 7 & Sangat lebih penting & $\begin{array}{l}\text { Suatu kegiatan yang favorit berkontribusi sangat kuat atas } \\
\text { yang lain, menunjukkan dominasi. }\end{array}$ \\
\hline 9 & Mutlak lebih penting & $\begin{array}{l}\text { Bukti yang menguntungkan satu kegiatan di atas yang lain } \\
\text { merupakan kemungkinan urutan afirmasi tertinggi. }\end{array}$ \\
\hline $2,4,6,8$ & $\begin{array}{l}\text { Untuk kompromi antara nilai- } \\
\text { nilai di atas }\end{array}$ & $\begin{array}{l}\text { Kondisi interpolasi penilaian kompromi secara numerik } \\
\text { karena tidak ada istilah yang pas untuk menggambarkan hal } \\
\text { tersebut }\end{array}$ \\
\hline
\end{tabular}

Skala nilai yang menunjukkan tingkat intensitas dari preferensi responden dapat dilihat pada Tabel 2. Skala ini diturunkan dari berbagai stimulus respon teori dan telah divalidasi efektivitasnya, tidak hanya dalam banyak aplikasi oleh banyak orang, namun juga melalui justifikasi teori akan skala apa saja yang harus digunakan untuk membandingkan unsur-unsur yang homogen (Saaty et al., 2013).

\section{Pengumpulan Data}

Secara umum, dalam metode AHP/ANP tidak membutuhkan data sampel dalam jumlah yang besar (Chou, 2018). Syarat responden yang valid dalam ANP adalah bahwa mereka adalah orang-orang yang menguasai atau ahli di bidangnya. Dengan begitu, responden akan secara tepat merepresentasikan pemahaman mereka terhadap faktor yang mempengaruhi pengambilan keputusan (Saaty et al., 2013). Random sampling (sampel acak) digunakan dalam penelitian ini untuk memilih 3 wilayah sampel Kabupaten di Indonesia, yaitu Pangkalan Bun, Katingan, dan Banyuasin.

Kuesioner didistribusikan kepada 49 responden yang merupakan petani ahli. Petani ahli didefinisikan sebagai petani yang mengetahui secara teknis proses pembudidayaan kelapa sawit dan memahami proses manajerial di dalam kemitraan, yang meliputi proses pengelolaan keuntungan, proses pembuatan dan pelaksanaan perjanjian dagang dengan perusahaan mitra, serta pengelolaan dana dan kebijakan peremajaan kebun. Umumnya, responden telah memiliki pengalaman menjadi petani sawit dan membangun kemitraan dengan perusahaan selama minimal 9 tahun.

Proses pengambilan data dilakukan melalui dua metode, yaitu melaui FGD (Forum Group Discussion) dan pengisian kuesioner yang dilakukan di tiap wilayah sampel. FGD dilakukan untuk mengumpulkan seluruh responden yang berada dalam satu wilayah kabupaten untuk terlebih dahulu menyamakan persepsi atas kuesioner yang akan diisi. Hal ini juga berkaitan dengan latar belakang sebagian responden yang belum pernah tergabung ke dalam seluruh jenis kemitraan sehingga penting untuk menyampaikan karakteristik dari ketiga jenis kemitraan sebagai alternatif pilihan ini. Diskusi juga akan dilakukan di akhir untuk menggali lebih dalam alasan pemilihan jawaban responden.

Proses pengisian kuesioner dilakukan di tengah proses FGD. Responden dipandu dalam pengisian kuesioner untuk memastikan bahwa responden paham akan kriteria dan alternatif yang disediakan serta memastikan jawaban yang dipilih responden konsisten.

\section{Analisis Data dengan Analytic Network Process (ANP)}

ANP merupakan pengembangan terhadap metode AHP (Analytic Hierarchy Process) yang berstruktur linier dan tidak mengakomodasi adanya timbal balik. Sebagai pengembangan dari metode AHP, ANP masih menggunakan cara Pairwise Comparison Judgement Matrics (PCJM) antar elemen yang sejenis (homogen). Perbandingan berpasangan ANP dilakukan antar elemen dalam komponen/kluster untuk setiap interaksi dalam jaringan (Rusydiana et al., 2013). Uji konsistensi data menjadi faktor penting baik dalam AHP maupun ANP. Uji ini penting untuk memastikan bahwa hasil penilaian yang ada sudah akurat dan reliabel (Son, 2014).

Dalam proses pengolahan dan analisis data ANP digunakan software SuperDecision yang dirancang untuk proses pengambilan keputusan. Input model jaringan dan nilai perbandingan berpasangan dari petani kemudian akan diolah oleh SuperDecision untuk mengetahui prioritas serta sintesis akhir dari model kemitraan yang menjadi prioritas petani sawit. Terdapat 4 supermatriks yang dihasilkan dari komputasi SuperDecision sebelum akhrinya diperoleh nilai prioritas akhir dari data ANP. Keempat supermatriks ini menggambarkan proses bagaimana sebuah prioritas dan sintesis akhir dihasilkan dari proses pengambilan keputusan dengan ANP. Supermatriks tersebut meliputi unweighted supermatrix, cluster matrix, weighted supermatrix, dan limit supermatrix. 
Unweighted supermatrix merupakan matriks yang dihasilkan dari data perbandingan berpasangan yang diperoleh dari hasil pengisian kuesioner. Di dalam ANP, pembobotan keterkaitan antar kluster tersusun dalam cluster matrix. Weighted supermatrix sendiri menunjukkan hasil perkalian antara komponen-komponen dalam unweighted supermatrix dengan cluster matrix. Terakhir, limit supermatrix merupakan weighted supermatrix yang telah dipangkatkan hingga memperoleh bobot angka yang stabil. Hasil dari limit supermatriks ini yang akan menentukan sintesis akhir dari prioritas kriteria pemilihan alternatif model kemitraan petani sawit ini.

\section{HASIL DAN PEMBAHASAN}

\section{Model Jaringan ANP}

Struktur timbal balik pada ANP tidak memiliki bentuk linier dari atas ke bawah tetapi lebih terlihat seperti jaringan, dengan lingkaran yang mengoneksikan antar kluster di dalamnya, dan dengan loops yang mengoneksikan nodes di dalam kluster itu sendiri (Saaty et al., 2013). Hal ini digambarkan dalam model jaringan ANP sebagai garis yang saling menghubungkan antar kotak kluster dan garis melingkar di dalam satu kotak kluster seperti pada Gambar 2.

Dalam penelitian ini terdapat 4 kluster yang terdiri dari kluster profitabilitas, sosial, peremajaan kebun (replanting), dan alternatif (alternatives). Masing-masing kluster terdapat kriteria yang merupakan komponen penyusunnya. Jaringan yang menghubungkan antar kriteria di dalam satu kluster dengan kriteria di dalam kluster lainnya disebut dengan outer dependence, sedangkan jaringan yang menghubungkan antar kriteria di dalam satu kluster disebut dengan inner dependence.

Inner dependence berada di dalam kluster profitabilitas dan sosial, dimana di dalamnya terdapat hubungan saling mempengaruhi antar kriteria di dalam masing-masing kluster profitabilitas dan sosial.

$\mathrm{P}=\mathrm{R}-\mathrm{C}$, dimana $\mathrm{R}=\mathrm{n} \times \mathrm{p}$

Keterangan:

$\mathrm{P}=$ Profitabilitas

$\mathrm{R}=$ Revenue

$\mathrm{C}=$ Cost

$\mathrm{n}=$ Jumlah produksi

$\mathrm{p}=$ Harga

Dalam profitabilitas terdapat suatu persamaan yang dinyatakan dalam persamaan 1 yang menyatakan bahwa besarnya profitabilitas petani sawit ditentukan oleh seberapa besar produksi TBS, harga dari TBS, dan seberapa besar biaya yang dikeluarkan untuk setiap TBS. Melalui persamaan tersebut diketahuai bahwa terdapat hubungan saling mempengaruhi antar kriteria di dalam kluster produktivitas.

Berdasarkan indikator triple bottom line, transparansi dipandang sebagai bentuk dari keadilan sosial sehingga adanya transparansi erat kaitannya dengan tingkat keadilan yang dirasakan petani. Adanya jaminan sosial yang terdiri dari jaminan kecelakaan kerja, jaminan kesehatan, dan jaminan pemutihan hutang biasanya diatur dalam perjanjian kemitraan/dagang dengan perusahaan mitra atau di dalam kemitraan itu sendiri.

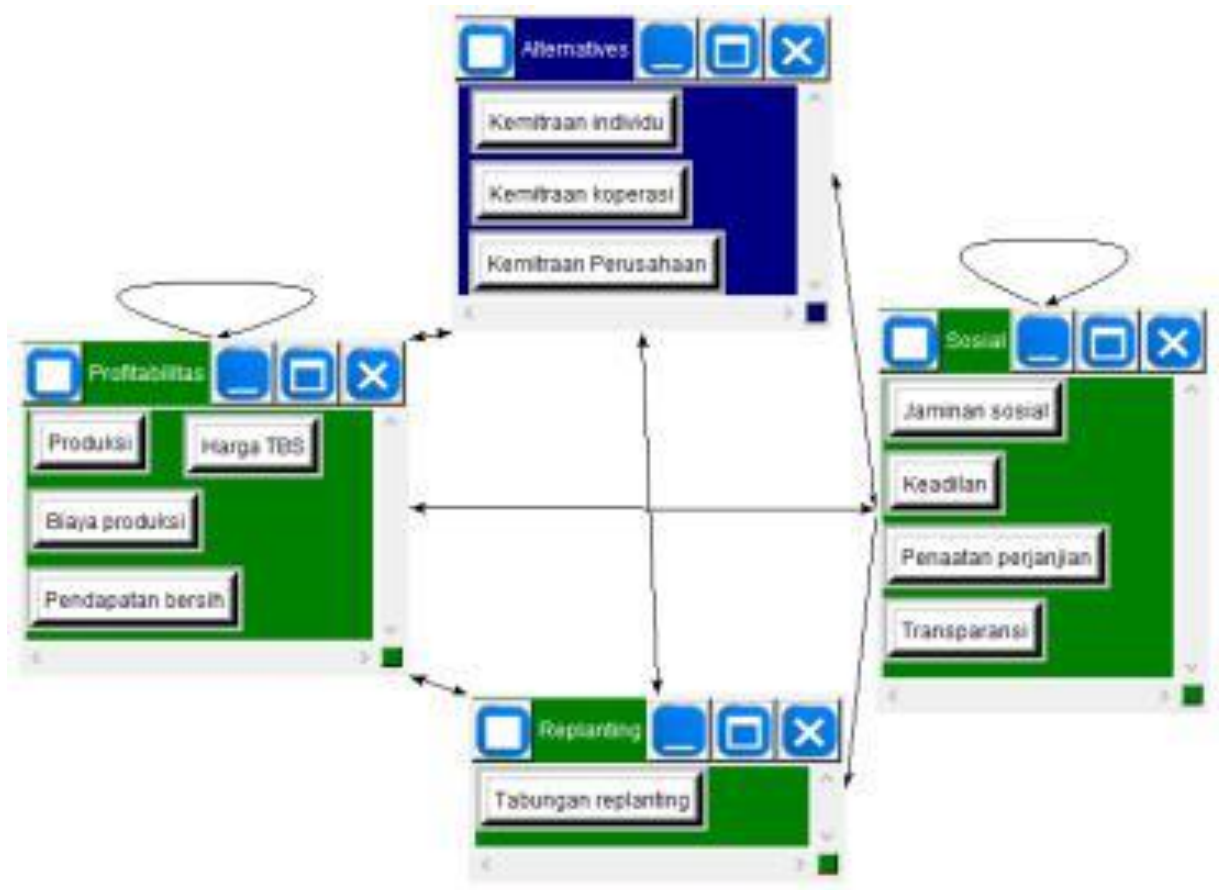

Gambar 2. Model jaringan ANP pemilihan jenis kemitraan petani sawit 
Jenis perjanjian dan penaatan terhadap perjanjian yang ada akan mempengaruhi jaminan sosial dan keadilan yang diterima petani. Dapat disimpulkan bahwa di dalam kluster sosial terhadap hubungan saling mempengaruhi antar elemen di dalamnya.

Outer dependence terdapat antara kriteria dalam kluster profitabilitas dengan sosial dan profitabilitas dengan peremajaan kebun yang digambarkan dengan garis panah dua arah. Garis panah satu arah menunjukkan hubungan antara kriteria dalam kluster sosial yang dipengaruhi oleh kriteria dalam kluster peremajaan kebun. Proses peremajaan kebun memerlukan biaya renovasi yang tinggi sehingga mempengaruhi besarnya pendapatan bersih petani yang merupakan hasil pengurangan antara revenue (total pendapatan) dengan biaya produksi. Begitu pula sebaliknya, semakin besar pendapatan petani maka petani dapat menyisihkan sebagian sebagai simpanan yang akan digunakan untuk peremajaan di masa mendatang.

Pendapatan bersih yang diterima petani tentunya ditentukan oleh aspek-aspek sosial, seperti keadilan dalam pembagian keuntungan, jaminan terhadap benefit yang diterima petani, penaatan terhadap kesepakatan harga dan pembagian keuntungan, serta transparansi proses pembentukan harga dan pembagian keuntungan yang ada. Sama halnya dengan pendapatan bersih, harga yang merupakan kompenen penentu seberapa besar pendapatan bersih petani juga dipengaruhi oleh proses perjanjian dan transparansi terhadap proses pembentukan harga yang dilakukan oleh perusahaan terhadap kemitraan petani.

Jaminan keberlanjutan usaha yang merupakan bagian dari jaminan sosial memerlukan ketersediaan dana peremajaan kebun untuk mengelola lahan sawit sehingga dapat tetap produktif. Oleh karena itu, dana peremajaan menentukan adanya jaminan bagi petani atau tidak.

\section{Perspektif Petani terhadap Kriteria dan Alternatif Model Kemitraan Kelapa Sawit}

Hasil kuesioner perbandingan berpasangan yang diisi oleh 49 petani digabungkan dengan menggunakan rerata geometrik. Rerata geometrik telah dibuktikan menjadi cara yang paling tepat dan unik untuk bisa menggambarkan hasil penggabungan nilai perbandingan berpasangan dari beberapa responden yang merepresentasikan nilai perbandingan berpasangan dari tiap responden itu sendiri (Saaty et al., 2013). Adapun persamaan rerata geometrik yang digunakan dapat dilihat pada persamaan 2 .

$a_{i j}=\sqrt[N]{\left(Z_{1} \times Z_{2} \times \ldots \times Z_{N}\right)}$, dimana $i, j=$

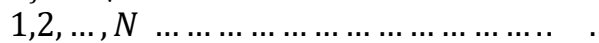

Keterangan:

$a_{i j}=$ nilai perbandingan berpasangan $e_{i}$ dengan $e_{j}$ untuk sejumlah $\mathrm{N}$ pengambil keputusan
$Z_{k}=$ nilai perbandingan berpasangan $e_{i}$ dengan $e_{j}$ yang dilakukan pengambil keputusan ke-k $(k=1,2, \ldots, N)$

Nilai rerata geometrik ini yang kemudian menjadi input dalam SuperDecision. Secara otomatis aplikasi akan menampilkan nilai inkonsistensi dari setiap input matriks perbandingan berpasangan. Inkonsistensi menunjukkan penyesuaian yang diperlukan untuk meningkatkan konsistensi perbandingan. Nilai dari rasio konsistensi yang diperlukan adalah kurang dari sama dengan 0,1 dimana ambang inkonsistensi yang diizinkan hanya 10\% (Saaty, 2008). Berdasarkan data yang diperoleh, diketahui bahwa seluruh matriks perbandingan berpasangan memiliki nilai inkonsistensi kurang dari 0,1 sehingga data dinyatakan layak untuk dilanjutkan ke tahap analisis selanjutnya. Nilai inkonsistensi yang dihasilkan dapat dilihat pada Tabel 4.

Tabel 4.Inkonsistensi data perbandingan berpasangan Matriks Perbandingan Berpasangan

Inkonsistensi

Perbandingan berpasangan antar

kluster

Perbandingan berpasangan antar

kriteria

Kluster profitabilitas

0,008

Kluster sosial

Perbandingan berpasangan antar alternatif

Kriteria biaya produksi

0,000

Kriteria harga TBS

Kriteria pendapatan bersih

0,004

Kriteria produksi

0,028

Kriteria tabungan peremajaan

kebun

0,012

Kriteria jaminan social

0,012

Kriteria keadilan

0,003

Kriteria penaatan perjanjian

0,003

Kriteria transparansi

0,001

\section{Prioritas dan Synthesize Akhir}

Hasil prioritas akhir pada keputusan memilih model kemitraan terbaik menurut petani sawit dapat dilihat pada Tabel 6 dan Tabel 7. Kolom local prioritize menunjukkan skor prioritas pada masingmasing kluster, sedangkan kolom global prioritize menunjukkan skor prioritas secara keseluruhan.

Pada kluster profitabilitas, kriteria yang menjadi prioritas tertinggi dalam model kemitraan adalah memastikan besarnya biaya produksi. Artinya penting bagi model kemitraan untuk menekan besarnya biaya produksi dan membuat proses produksi menjadi lebih efisien. Kemudian pada kluster sosial, penaatan perjanjian menjadi kriteria yang penting dalam model kemitraan yang artinya suatu kemitraan harus memiliki mekanisme yang dapat memastikan proses penaatan perjanjian terjadi dengan baik. 
Tabel 6. Hasil Prioritas Akhir

\begin{tabular}{llcc}
\hline \multicolumn{1}{c}{ Kluster } & \multicolumn{1}{c}{ Kriteria } & Local Prioritize & Global Prioritize \\
\hline Alternatif & Kemitraan individu & 0,206 & 0,056 \\
& Kemitraan koperasi & 0,457 & 0,125 \\
Profitabilitas & Kemitraan perusahaan & 0,337 & 0,092 \\
& Biaya produksi & 0,339 & 0,087 \\
& Harga TBS & 0,213 & 0,055 \\
Peremajaan Kebun Tabungan peremajaan kebun & 0,228 & 0,059 \\
Sosial & Pendapatan bersih & 0,219 & 0,056 \\
& Jaminan sosial & 1,000 & 0,107 \\
& Keadilan & 0,063 & 0,023 \\
& Penaatan perjanjian & 0,102 & 0,037 \\
& Transparansi & 0,395 & 0,159 \\
\end{tabular}

Tabel 7. Prioritas kriteria dalam menentukan jenis kemitraan

\begin{tabular}{lcc}
\hline Kriteria & Prioritas & Ranking Prioritas \\
\hline Penaatan perjanjian & 0,159 & 1 \\
Transparansi & 0,143 & 2 \\
Tabungan peremajaan kebun & 0,107 & 3 \\
Biaya produksi & 0,087 & 4 \\
Pendapatan bersih & 0,059 & 5 \\
Produksi & 0,056 & 6 \\
Harga TBS & 0,055 & 7 \\
Keadilan & 0,037 & 8 \\
Jaminan sosial & 0,023 & 9 \\
\hline
\end{tabular}

Berdasarkan tabel 7 di atas, diketahui bahwa 3 kriteria terpenting bagi petani dalam model kemitraan yang terbaik adalah (1) Penaatan perjanjian; (2) Transparansi; dan (3) Tabungan peremajaan kebun. Baik penaatan perjanjian maupun transparansi memiliki bobot yang tidak terlalu jauh atau hanya terpaut 0,016 . Artinya penaatan perjanjian dan transparansi memiliki tingkat kepentingan yang hampir sama dalam pengembangan model kemitraan.

Temuan di lapangan menunjukkan bahwa faktor sosial tersebut memiliki prioritas paling besar dalam model kemitraan. Suatu kemitraan didefinisikan sebagai kerja sama antara beberapa entitas legal yang didasarkan pada perjanjian kemitraan (kontrak) (Grundey et al., 2009), sehingga penataan dalam perjanjian merupakan hal yang sangat berpengaruh terhadap berlangsungnya sebuah kemitraan. Dari perspektif petani, kriteria ini sangatlah penting karena daya tawar mereka yang sering kali lebih rendah dari perusahaan. Salah satu aturan yang telah pemerintah terbitkan adalah Permentan Nomor 01/PERMENTAN/ KB.120/1/2018 tentang Penetapan Harga Pembelian Tandan Buah Segar Kelapa Sawit Produksi Pekebun. Bentuk perjanjian lainnya juga muncul dalam perjanjian konversi pembayaran pembangunan kebun dengan pola KKPA.

Meskipun secara tertulis sudah terdapat kesepakatan atau aturan yang mengatur, namun dalam implementasinya seringkali terjadi ketidaksesuaian dan tidak adanya transparansi pelaksanaan kerjasama. Data dilapangan juga menunjukkan bahwa sedikit sekali petani dari berbagai kemitraan yang memahami pembagian bunga pendapatan dari tabungan peremajaan kebun. Oleh karena itu, regulator harus memastikan adanya mekanisme edukasi petani, pengawasan, dan penegakan aturan atas perjanjian yang telah disusun. Dengan berfungsinya peran pemerintah sebagai regulator dan pengawas kebijakan diharapkan dapat meningkatkan daya tawar petani dalam kemitraan sehingga diharapkan pula dapat menciptakan model kemitraan yang efektif, efisien, dan adil.

Transparansi menjadi prioritas selanjutnya bagi petani sawit dalam model kemitraan. Konsep Triple Buttom Line sendiri menempatkan transparansi sebagai aspek penting dalam menjamin keberlanjutan usaha, bahwa akuntabilitas merupakan suatu keharusan dalam bisnis (Jackson et al., 2011). Dengan adanya transparansi maka suatu bisnis dianggap mampu meningkatkan kedekatan (engagement) dengan masyarakat sekitarnya, atau dalam hal ini dengan mitra usahanya sehingga petani dapat ikut terlibat dalam setiap pengambilan keputusan atau setidaknya mengetahui proses dari pengambilan keputusan tersebut. $\mathrm{Di}$ sisi lain, perusahaan juga mendapat keuntungan dari tingkat kepercayaan petani terhadap kinerja perusahaan sehingga dapat menjadi mitra strategis.

Kriteria tabungan peremajaan kebun kemudian menjadi prioritas ketiga dalam model kemitraan terbaik menurut petani. Hal ini berkaitan dengan keberlanjutan usaha perkebunan kelapa sawit yang dalam jangka waktu tertentu memerlukan peremajaan tanaman sehingga adanya mekanisme sumber pendanaan peremajaan kebun, skema 
peremajaan kebun pada kemitraan, dan skema pembagian bunga pendapatan peremajaan kebun pada kemitraan yang sesuai dianggap penting untuk menjadi pertimbangan. Peremajaan kebun juga dianggap sebagai salah satu faktor terpenting yang mempengaruhi keberhasilan program revitalisasi perkebunan kelapa sawit, disamping peningkatan produktivitas perkebunan, dan pembiayaan perkebunan (Hidayati et al., 2018).

Kriteria-kriteria yang masuk ke dalam kluster profitabilitas menempati urutan empat ke bawah dikarenakan adanya anggapan bahwa dengan hadirnya kepastian perjanjian dan transparansi serta jaminan keberlangsungan usaha melalui skema peremajaan kebun maka akan secara otomatis meningkatkan profitabilitas petani sawit.

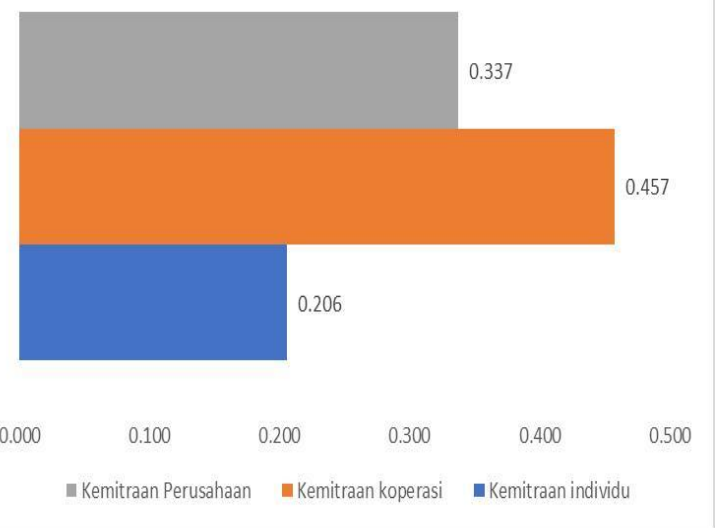

Gambar 3. Synthesize akhir prioritas alternatif

Tabel 8. Hasil synthesize akhir alternatif

\begin{tabular}{lcll}
\hline Name & Ideals & Normals & Raw \\
\hline Kemitraan individu & 0,450 & 0,206 & 0,056 \\
Kemitraan koperasi & 1,000 & 0,457 & 0,125 \\
Kemitraan perusahaan & 0,737 & 0,337 & 0,092 \\
\hline
\end{tabular}

Alternatif jenis kemitraan yang menjadi pilihan utama petani sawit adalah jenis kemitraan koperasi, diikuti dengan kemitraan perusahaan, dan kemitraan individu dengan skor preferensi 0,457; 0,337; dan 0,206 yang bersumber dari nilai limit supermatrix. Kemitraan koperasi dianggap petani memiliki keunggulan pengelolaan kemitraan dibanding kemitraan lain dalam hal mampu menekan biaya produksi, menghasilkan pendapatan bersih yang tinggi, meningkatkan produksi TBS, mekanisme tabungan peremajaan kebun yang memuaskan, pengelolaan jaminan sosial yang baik, adil, dan lingkungan yang transparan. Pada kriteria biaya produksi misalnya, petani memiliki kecenderungan/preferensi bahwa kemitraan koperasi lebih baik dalam mengelola biaya produksi sehingga dapat lebih murah dan efisien. Skor preferensi petani bahkan mencapai 2 kali lipat dari kemitraan perusahaan maupun kemitraan individu, yaitu senilai 0,5 sedangkan lainnya hanya sebesar 0,3 dan 0,2.

Berdasarkan preferensi petani terhadap alternatif jenis kemitaan yang didasarkan atas kriteria-kriteria di atas, terdapat dua prioritas kriteria utama yang dianggap mampu dipenuhi oleh jenis kemitraan koperasi, yaitu kriteria transparansi dan tabungan peremajaan kebun. Kemitraan koperasi dianggap petani memiliki transparansi yang lebih baik dibandingkan pada kemitraan perusahaan dan kemitraan individu. Skor preferensi petani terhadap kemitraan koperasi atas kriteria ini senilai 0,5 sedangkan kemitraan perusahaan dan individu masing-masing 0,4 dan 0,2. Pada mekanisme tabungan peremajaan kebun, petani memiliki preferensi yang tinggi terhadap jenis kemitraan koperasi dengan skor 0,5 sedangkan kemitraan perusahaan sekitar 0,3 dan kemitraan individu hanya 0,2 .

Hasil ini diperkuat dengan hasil wawancara yang menyebutkan bahwa sudah ada mekanisme tabungan peremajaan kebun dan transparansi pada kemitraan koperasi yang menjadi informan penelitian, khususnya Koperasi Karya Tani di Kotawaringin Barat (Sutarno, Koperasi Karya Tani, 2019). Koperasi Karya Tani sendiri memutuskan untuk menyimpan sisa hasil penjualan (SHP) tandan buah sawit untuk keperluan persiapan peremajaan pada tahun 2011 agar koperasi lebih mandiri (Eko, Koperasi Karya Tani, 2019). Tabungan bersumber dari kas koperasi yang berasal dari simpanan wajib dan simpanan pokok. Data keuangan juga dapat dilihat di laporan akhir tahun yang dapat diakses oleh seluruh anggota. Setiap petani sudah memiliki tabungan peremajaan kebun senilai $\mathrm{Rp}$ 12.000.000 per kapling dari dipotong penyisihan sisa hasil penjualan (SHP) dengan besaran potongan didasarkan pada kesepakatan antara petani pemilik kapling (Warno, Koperasi Karya Tani, 2019).

Sebaliknya, kemitraan perusahaan dianggap memiliki keunggulan dalam hal penataan perjanjian dan harga TBS yang lebih tinggi. Skor preferensi petani terhadap kemitraan perusahaan atas kriteria harga TBS adalah 0,5 sedangkan pada kemitraan koperasi dan individu senilai 0,4 dan 0,2. Artinya, kemitraan perusahaan dianggap lebih baik dalam memberikan kepastian harga dan nilai jual TBS yang lebih baik bagi petani. Pada kriteria penaatan perjanjian, kemitraan perusahaan dianggap petani lebih baik dibandingkan kemitraan koperasi dan individu, yaitu dengan skor preferensi sebesar 0,44 sedangkan yang lainnya sebesar 0,4 dan 0,2 .

Kemitraan individu tidak dianggap lebih baik oleh petani dalam kriteria apapun sehingga model kemitraan ini dapat dianggap tidak memiliki keuntungan yang lebih baik bagi petani dibandingkan kedua jenis kemitraan yang lainnya. Di sisi lain, jika ingin mengoptimalkan peran kemitraan koperasi dalam mensejahterakan petani maka diharapkan dapat lebih kooperatif dalam skema penyusunan 
perjanjian dan pelaksanaan perjanjian kemitraan. Hal ini dikarenakan kriteria penaatan perjanjian pada kemitraan koperasi tidak dianggap petani lebih baik dibandingkan kemitraan perusahaan, padahal kriteria tersebut merupakan salah satu kriteria utama yang menjadi prioritas petani dalam model kemitraan yang terbaik menurut preferensinya.

\section{Gambaran Teknis Manajerial Kemitraan Koperasi}

Kemitraan koperasi yang dimaksud merupakan kemitraan model inti-plasma dimana usaha perkebunan akan dikelola oleh koperasi. Anggota koperasi adalah petani kelapa sawit, baik petani sebagai pemilik lahan maupun petani buruh. Anggota koperasi harus turut berpartisipasi dalam proses manajemen perkebunan dan dalam mencapai tujuan utama. Tingkat partisipasi anggota dapat berupa berpartisipasi dalam menjaga keberlanjutan organisasi, partisipasi pada investasi baik dengan membayar iuran wajib maupun iuran sukarela, serta partisipasi dalam proses bisnis koperasi.

Dalam kemitraan skema koperasi terdapat opsi dimana petani juga dapat melakukan aktivitas bisnis secara langsung dengan pihak diluar koperasi. Petani dapat membeli tambahan input TBS dari independent plot dan menjual TBS-nya ke perusahaan pengolahan TBS secara langsung. Petani buruh yang mengelola lahan koperasi juga dapat memperoleh upah dari koperasi. Disisi lain, koperasi bertanggung jawab untuk mencapai kesepakatan terbaik (agreement) dengan perusahaan mitra, memberikan keterbukaan informasi pada anggotanya, mengelola pendapatan usaha perkebunan salah satunya dana peremajaan kebun untuk memastikan keberlanjutan usaha, serta membagi risiko usaha perkebunan melalui mekanisme yang adil (Suharno et al., 2015).

Kinerja koperasi akan dipengaruhi oleh peran stakeholder, partisipasi anggota, karakter stakeholder, serta kesejahteraan petani (Lukman et al., 2019). Oleh karena itu, dalam implikasi manajerial perlu mempertimbangkan aktor-aktor yang terlibat dalam kemitraan tersebut. Implikasi manajerial yang dapat dilakukan dalam kemitraan koperasi seperti: (1) Pengurus koperasi dinilai perlu untuk melakukan advokasi dalam kemitraan dengan perusahaan untuk memastikan ketaatan terhadap perjanjian kemitraan. Salah satu jenis perjanjian yang dalam implementasinya ditemukan ketidaksesuaian adalah perjanjian penetapan harga TBS yang sudah diatur pula dalam Permentan Nomor 01/PERMENTAN/KB.120/1/2018 tentang Penetapan Harga Pembelian Tandan Buah Segar Kelapa Sawit Produksi Pekebunan. Dengan demikian, adanya intervensi pemerintah dalam hal pengawasan dan evaluasi implementasi aturan juga dinilai perlu dilakukan; (2) Pengurus koperasi serta perusahaan dinilai perlu untuk memberikan keterbukaan informasi di dalam kemitraan, terutama dalam operasional bisnisnya. Transparasi dinilai mampu meningkatkan kepercayaan (trust) dalam kemitraan; serta (3) Pengurus koperasi, perusahaan mitra, dan anggota koperasi dinilai perlu mempertimbangkan dan merencanakan tabungan peremajaan kebun sebagai upaya untuk melakukan revitalisasi perkebunan kelapa sawit dan keberlanjutan usaha perkebunan.

\section{KESIMPULAN DAN SARAN}

\section{Kesimpulan}

Kriteria dalam model kemitraan sawit yang menjadi prioritas petani adalah penaatan perjanjian, transparansi, dan tabungan peremajaan kebun dengan skor masing-masing 0,$159 ; 0,143$; dan 0,107 sehingga penting untuk memastikan dan mengoptimalkan ketiga hal tersebut dalam kemitraan sawit.

Alternatif model kemitraan yang paling baik menurut preferensi petani sawit di 3 wilayah sampel adalah jenis kemitraan koperasi dengan skor 0,457; diikuti dengan kemitraan perusahaan senilai 0,337 ; dan kemitraan individu senilai 0,206.

\section{Saran}

Untuk mencapai kondisi ideal pada kemitraan koperasi, maka perlu ditingkatkan mekanisme pengawasan dan penegakan aturan dari pemerintah terhadap implementasi perjanjian dan transparansi di dalam kemitraan. Pengawasan dapat dimulai dari penyusunan perjanjian kemitraan, mekanisme peremajaan kebun, keterbukaan proses pembentukan harga, keterbukaan pengelolaan laba, serta proses implementasi kebijakan. Berkembangnya teknologi informasi juga dapat menjadi solusi dalam meningkatkan kualitas dari kriteria utama tersebut. Pemerintah, perusahaan, dan petani dapat saling terintegrasi secara real time melalui sistem informasi digital.

\section{UCAPAN TERIMA KASIH}

Terima kasih peneliti ucapkan kepada BPDP Sawit atas pendanaan yang telah diberikan untuk melaksanakan penelitian ini. Selanjutnya, terima kasih juga kepada seluruh petani sawit di wilayah kabupaten Pangkalan Bun, Katingan, dan Banyuasin yang telah melibatkan diri dalam aktivitas pengumpulan data.

\section{DAFTAR PUSTAKA}

Chou C. 2018. Application of ANP to the selection of shipping registry: the case of Taiwanese maritime industry. International Journal Industrial Ergonomics. (67): 89-97.

Direktorat Jenderal Perkebunan Kementerian Pertanian. 2017. Statistik perkebunan indonesia komoditas kelapa sawit 2015-2017. Jakarta: Direktorat Jenderal Perkebunan.

Grundey D dan Daugelaite I. 2009. Developing business partnership on the basis of internal 
marketing. Journal Economic and Sociology, 2 (1): 118-130.

Hamid E, Fathoni Z, dan Yanita M. 2018. Palm oil sustainability partnership: implementation and connection with farmers income. E3S Web of Conferences 52 published by EDP Sciences.

Harvard Business Review (HBR). 2019. 25 years ago $i$ coined the phrase "triple bottom line." Here's why it's time to rethink it. Tersedia dari: https://hbr.org/2018/06/25-years-ago-icoined-the-phrase-triple-bottom-line-hereswhy-im-giving-up-on-it.

Hidayati J, Sukardi S, Suryani A, Fauzi AM, Sugiharto S. 2018. Palm oil plantation revitalization model for agroindustry development. International Journal on Advanced Science Engineering Information Technology. 8 (2): 588-592.

Hourneaux F, Gabriel MLdS, dan Vazquez DAG. 2018. Triple buttom line and sustainable performance measurement in industrial companies. Journal Revista de Gestao. 25 (4): 413-429.

Ikatrinasari ZF, Maarif MS,. Sa'id EG, Bantacut T, Munandar A. 2011. Model pemilihan kelembagaan agropolitan berbasis agroindustri dengan analytical network process. Jurnal Teknologi Industri Pertanian 3(19): 130-137.

ISPOC. 2012. Indonesian Sustainable Palm Oil System. Indonesian palm oil in numbers 2012. Jakarta, Indonesia: Indonesian Sustainable Palm Oil Commission.

Jackson A, Boswell K, Davis D. 2011. Sustainability and triple buttom line reporting-what is it all about? International Journal Business, Humanities and Technology. 1(3): 55-59.

Jeon J, Kim J, Park Y. Lee H. 2016. An analytic network process approach to partner selection for acquisition and development. Journal Technology Analysis and Strategic Management. 29 (7): 790-803.

Lukman IA, Ismali M, Sasongko, Budi D. 2019. Palm oil plantation partnership's performance in Kuantan Singingi Region. The International Journal Accounting and Business Society. 27. (2): 92-114.

Milsa M. 2015. Tinjauan yuridis perjanjian pola kemitraan perkebunan kelapa sawit inti- plasma antara PT. Boswa Megalopolis dengan masyarakat (Suatu Penelitian Di Kabupaten Aceh Jaya). Premise Law Journal. 4 : 1-20.

Nurhayati A, Bair M, Hadayani, Wahyuningsih. 2016. Partnership pattern, strategy and income of oil farming of PT Lestari Tani Teladan in Donggala, Central Sulawesi International Journal Business and Management Invention, 5(8):94-101.

Oktaby NZ. 2014. Koperasi di kebun sawit: studi kasus perubahan fungsi dan peran Koperasi Unit Desa SP II Bhakti Jaya, Kecamatan Meliau, Kabupaten Sanggau, Kalimantan Barat. [Electronic Theses \& Dissertations]. Yogyakarta: Universitas Gadjah Mada.

Rusydiana AS, dan Devi A. 2013. Analytic Network Process: Pengantar Teori dan Aplikasi. Bogor: Smart Publishing.

Saaty TL. 2008. The analytic network processes. Iranian Journal Operations Research. 1(1): 127.

Saaty TL dan Vargas LG. 2013. Decision making with The Analytic Network Process: economic, political, social and technological applications with benefits, opportunities, costs and risks. Springer Science \& Business Media. USA.

Sadeghi M, Rashidzadeh MA, dan Soukhakian MA. 2012. Using analytic network process in a group decision-making for supplier selection. Journal Informatica. 23 (4): 621-643.

Son LN. 2014. Consistency test in ANP method with group judgment under intuitionistic fuzzy environtment. International Journal of Soft Computing and Engineering. 4(3): 68-71.

Suharno YA, Dehen B, Barbara, Ottay JB. 2015. Opportunities for increasing productivity and profitability of oil palm smallholder farmers in Central Kalimantan. Published by Palangkaraya Institute for Land Use and Agricultural Research, Fakultas Pertanian, Universitas Palangkaraya, Kalimantan Tengah.

The Economist. 2009. Idea: Triple Bottom Line. Tersedia dari: https://www.economist.com/news/2009/11/17 /triple-bottom-line 